\title{
Hot Spot Analysis of Photovoltaic Module under Partial Shading Conditions by Using IR-Imaging Technology
}

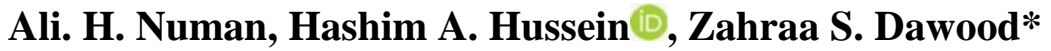 \\ Department of Electromechanical Engineering, University of Technology, Baghdad, Iraq. \\ *Corresponding author Email: ahnuman2001@gmail.com
}

\section{H I G H L I G H T S}

- Output power losses of PV module during irradiance transitions were studied.

- The maximum output power loss of PV module under hot spot was around 52.86\%.

- The temperature difference between the hottest and cooled cell was about $6^{\circ} \mathrm{C}$.

\section{A R T I C L E IN F O}

Handling editor: Muhsin J. Jweeg

\section{Keywords:}

PV module

Partial shading

Hotspot

Thermography

I-V characteristics

Reliability

\author{
A B S T R A C T
}

\begin{abstract}
The probable appearance of localized overheating (hot spot) represents one of the main matters for the reliability and safety of $\mathrm{c}$-Si cells. It entails both a risk for the photovoltaic module's lifetime and a decrease in its operational efficiency. Partial shading is the most common cause of a hot spot in a PV system. The main aim of this work is to analyze the hotspot phenomena by I-V curve as well as IR thermography and investigate the impact of partial shading on the hottest cell experimentally to find its effect on the output power. The results show that at normal operating conditions $\left(\mathrm{G}=865 \mathrm{~W} / \mathrm{m} 2\right.$ and $\left.\mathrm{Ta}=39.7^{\circ} \mathrm{C}\right)$ the output power is $89.05 \mathrm{~W}$; the temperature difference between the hottest and cooled cell was about $6^{\circ} \mathrm{C}$. Moreover, the short circuit current and consequently, the maximum output power reduced if only one cell fully or partially shaded. However, when the hottest cell is shaded by $25 \%, 50 \%, 75 \%$, and $100 \%$ of the shaded area, the power losses were $37.17 \%, 50.05 \%, 48.61 \%$, and $52.86 \%$ respectively. Wheals, the hottest cell temperature was $80.6,99.1,101.4$, and $62.4^{\circ} \mathrm{C}$ for $25,50,75$, and $100 \%$ of the shading area, the major temperature difference observed at $75 \%$ of the shading area.
\end{abstract}

\section{Introduction}

Among various forms of renewable energy, the deployment of photovoltaic solar power increasing rapidly due to their advantages such as freedom from environmental pollution, low maintenance cost, and absence of moving or rotating parts [1, 2]. The overall capacity of photovoltaic (PV) is over $31 \mathrm{GW}$ in 2012 and increase to 84 GW by 2017 according to the aggressive projection following the technical reports of the European photovoltaic industry association (EPIA) [3]. The probable appearance of localized overheating (hot spot) represents one of the main matters for the reliability and safety of c-Si cells [4]. It entails both a risk for the photovoltaic module's lifetime and a decrease in its operational efficiency. A hot-spot consists of a localized overheating in a photovoltaic (PV) module. The anomalies that cause hot-spots can be external to the PV module: shading or dust or internal: micro-cracks defective soldering potential induced degradation material imperfections [5]. In general, the shaded cells can get reverse biased and start consumption power rather than producing power which causes decreases in the total output power due to losing power. The loss power would cause topical heating and raise the temperature produce thermal stress on the entire panel and cause hot spots, rapidly increasing temperature leads to melting the encapsulate, like EVA, and break down the back sheet-like TPT, the reverse bias on the solar cell under severe cases of shading might overstep its breakdown voltage. In such cases, the cell gets fully damaged, develops cracks and an open circuit can occur at the serial branch where the cell is linked [6], [7]. Bypass diodes connected in antiparallel with the photovoltaic cells to counteract the destructive impact of shading [8], [9]. In general, these diodes limited the reverse voltage on the shaded cell to avoid voltage from interring to the breakdown voltage region. However, hot-spot may still occur even if bypass diodes are inserted [10]. Due to crystal impurities and defects, some cells exhibit a large reverse current, even before reaching the breakdown voltage [8], [10], [4]. C. Buerhop et al. [11] analyzed about 260 PV modules analyzed by I-V curve as well as IR thermography to investigate the reliability of IR images under real-time long term environmental conditions. The measured output power of the PV module is reduced by $11 \mathrm{~W}$ due to the hot spot affecting the PV module. A. M. Salazar and E. B. Macabebe [12] detected the hotspot location in PV module by employing an infrared thermography technique. Polycrystalline module has 
been tested under partial shading which results from adhesive remains on its surface. The hot spot area was $4.54 \%$ before removing the shading factor and then it reduced to $1.61 \%$ after removing the shading factor which corresponds to the localized heating at the junction box. A. Dolara et al (2016) [13] explained the hot spot phenomena which occurred in PV systems during the normal operation of modules under partial shading condition due to overhead line wires with a path crossing the PV filed. Small increase in temperature was recorded during the I-V curve measurement. Besides, there is no significant reduction in energy generated. Furthermore, in PV plant influenced by shading due to an overhead power line, the currents and voltages were observed and registered. M. Dhimish et al [14]: investigated partial shading on PV module by using opaque paper as a shading element. Multiple experiments has been conducted under various shading condition (the module has been shaded by $10,20,30,40,50,60,70,80$ and $90 \%$ ) to analyzed the I-V and P-V curves of PV module. Moreover, two modules were used to conduct the hotspot tests. By using i5FLIR thermal imaging camera, one module appeared with a hot spot while the other was healthy (without hot spot). I-V curve of the hot spotted PV module is compared with a healthy PV module under 621 $\mathrm{W} / \mathrm{m} 2$ of solar irradiance and the PV modules temperature is approximately equal to $18.2{ }^{\circ} \mathrm{C}$. the power loss due to the hot spot in the examined PV module is equal to $5.78 \mathrm{~W}$.

This paper aimed to analyze the hotspot phenomena in PV module by IR-imaging technology as a reliable and fast fault detection method and I-V curve. Thermal images, I-V and P-V characteristics curve of PV module under partial shading of the hottest cell have been conducted and analyzed. The practical test was carried out at the site of the Department of Electromechanical Engineering/ University of Technology located along the longitude $44.44^{\circ}$ and latitude $33.31^{\circ}$ during July 2019.

\section{Experimental setup}

To explain and analyze the hot spot phenomena, the monocrystalline solar module was tested at normal operating conditions. The experiment equipment is shown photographically and schematically as in Figure 1 and Figure 2 respectively. This equipment is PV module, variable resistance (load), IR camera, some cover to shaded the test cells, two digital multimeter to measure the DC and voltage of the PV module, a solar meter, and the humidity and temperature device. The measuring data include solar radiation, output current and voltage, environmental temperature and humidity, and solar panel surface temperature. Table 1 explains the electrical characteristics of the PV panel under the standard test condition, Fluke imager Ti32 infrared camera was utilized in this study. It has the following specifications:

a) The field of view and minimum focus distance (with standard lens) are $23^{\circ} \times 17^{\circ}$ and $15 \mathrm{~cm}$, respectively.

b) The infrared spectral band range is 8.0 to $14 \mu \mathrm{m}$ (long-wave) and accuracy $\pm 2{ }^{\circ} \mathrm{C}$ or $2 \%$.

c) The pixel detector is $320 \times 240$.

Table 1: Electrical characteristic of Monocrystalline solar panel

\begin{tabular}{lc}
\hline Maximum Power (Pmax) & $150 \mathrm{~W}$ \\
Maximum Power Voltage (Vmax) & $17.8 \mathrm{~V}$ \\
Maximum Power Current (Imax) & $8.4 \mathrm{~A}$ \\
Open Circuit Voltage (Voc) & $22.4 \mathrm{~V}$ \\
Short Circuit Current (Isc) & $9.19 \mathrm{~A}$ \\
Module Efficiency & $14.99 \%$ \\
No. of cells connected in series (NS) & 36 \\
No. of cells connected in Parallel (NP) & 1 \\
\hline
\end{tabular}

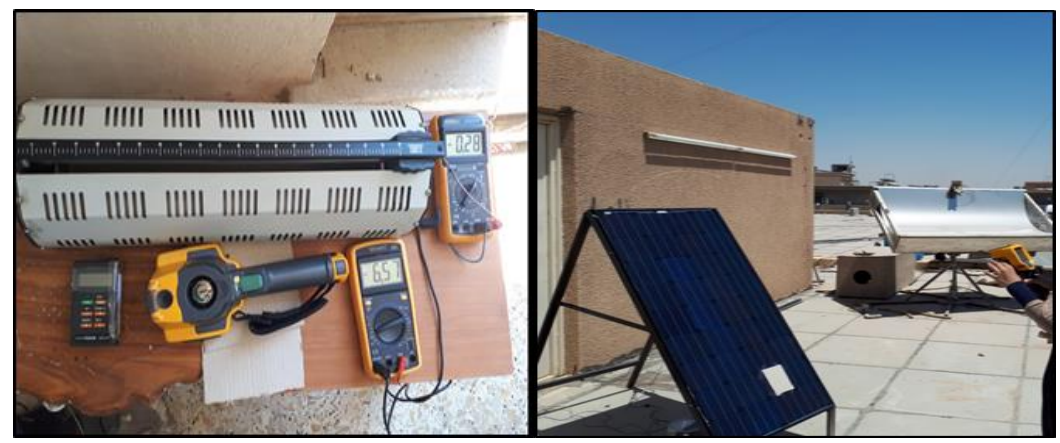

Figure 1: Photographs of instruments used to examine the hot spotted PV module (PV module, Ammeter, voltmeter, solar meter, shading elements and IR-Camera (Fluke Ti32)). 


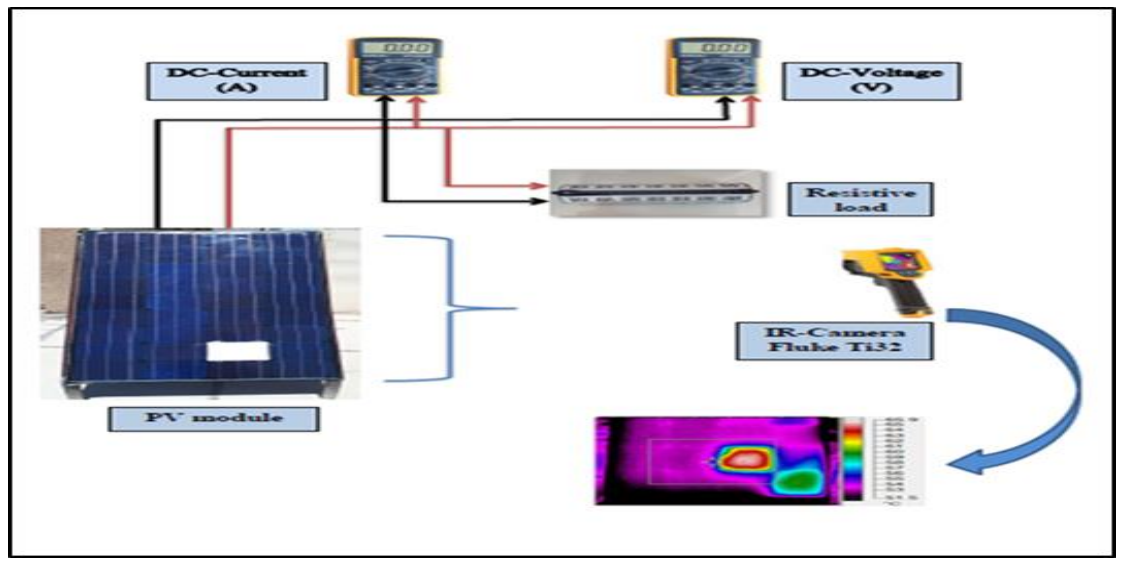

Figure 2: Structure and instruments used to examine the hot spotted PV modules

It can display the object temperature within the range of $-10^{\circ} \mathrm{C}$ to $+150^{\circ} \mathrm{C}$. In this case, e $=0.91$ was used, within the typical value range for glass, transmission correction $=100 \%$, background temperature were setting at each test according to read of Digital meter sensor type UNI-T UT332. The distance between the PV module and the camera was variable (at least $1 \mathrm{~m})$. Furthermore, the images should be taken at a camera angle between $15^{\circ}$ and $40^{\circ}$ to avoid casting a shadow on the PV module.

\subsection{Identification of the hottest cell}

Firstly, the PV module (monocrystalline with 36 solar cells) was shorted and exposed to solar radiation (at least 700 $\mathrm{W} / \mathrm{m} 2$ ) to Measurements of the I-V characteristic and determines the corresponding power. Next, the PV module was shorted and exposed to sunlight radiation for about 2 hours, during which time thermal images of the module were acquired using a thermal imaging camera. The hottest cell of the module was identified by comparing the different maximum surface temperatures of the cells. The thermal imaging must be taken carefully as possible to ensure the appropriate identification of the hottest cell.

\subsection{Increasing shading area of the hottest cell}

In this section, Insulated paper (Cardboard) with different sizes used to cover at least $25 \%, 50 \%, 75 \%$, and $100 \%$ of the same hottest cell surface to find their impact on the power output as shown in Figure 3.

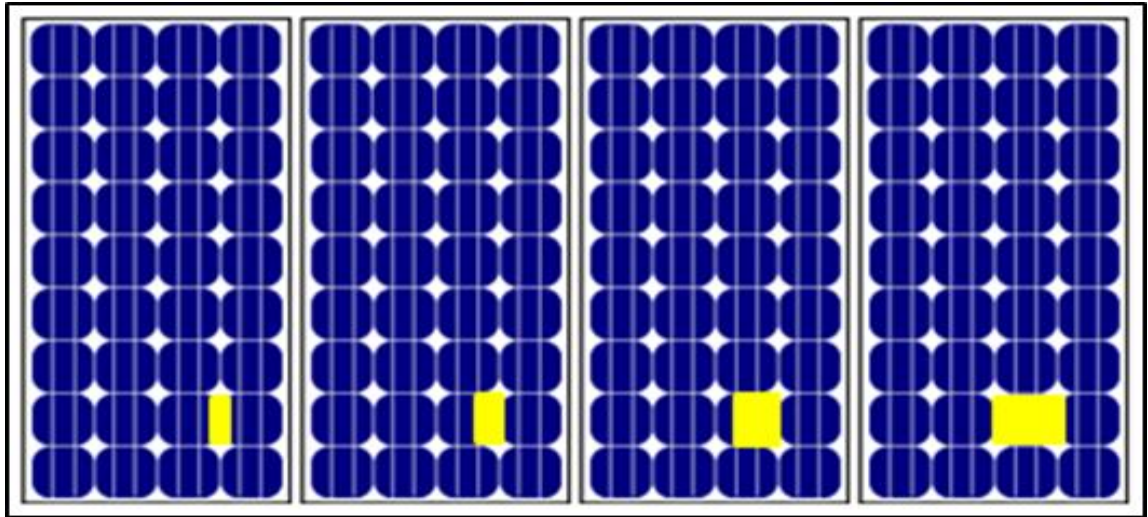

Figure 3: Different percentage of shaded area $(25 \%, 50 \%, 75 \%$ and $100 \%)$ for single-cell by employed insulated material (cardboard)

\section{Results and Discussion}

\subsection{Identification of the hottest cell}

The hottest cell was identified during7th July 2019, by comparison, the surface of the temperature of the PV module when solar radiation is $865 \mathrm{~W} / \mathrm{m} 2$ and environmental temperature is $40.2^{\circ} \mathrm{C}$; the acquired $\mathrm{I}-\mathrm{V}$ and corresponding P-V shown in Figure 4. The measured parameters are Isc of 7.89A, the Imax of $6.54 \mathrm{~A}$, the Vmax of $13.25 \mathrm{~V}$, and the Pmax of 86.7W. The surface of the tested module was divided into three sections to find the accurate position of the hottest cell as shown in Figure 5. By comparing temperature in the three images, it can be noticed that the hottest cell lies in the lower section of the PV module; the identified cell is on the eighth row, in the third position starting from the left due to crystal impurities and defects. The hottest cell temperature was $62.3^{\circ} \mathrm{C}$ while the temperature of the cooled cell was about $56.3^{\circ} \mathrm{C}$. This means that the temperature difference between the hottest and cooled cells was about $6^{\circ} \mathrm{C}$. 


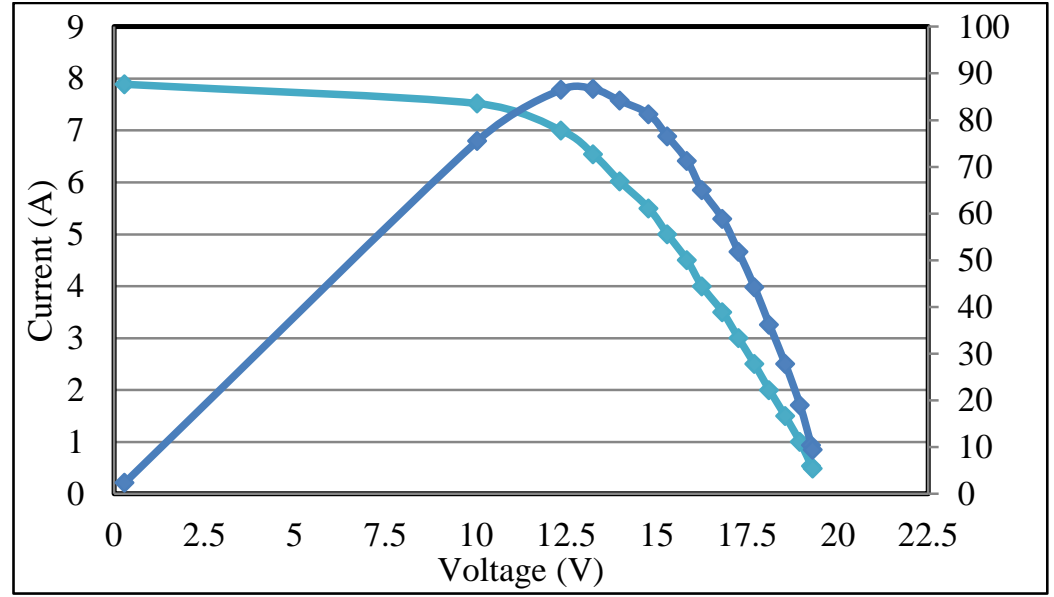

Figure 4: $\mathrm{I}-\mathrm{V}$ and $\mathrm{P}-\mathrm{V}$ characteristics curve of $\mathrm{PV}$ at normal operating conditions $(\mathrm{G}=865 \mathrm{~W} / \mathrm{m} 2$, $\left.\mathrm{Ta}=40.2^{\circ} \mathrm{C}\right)$

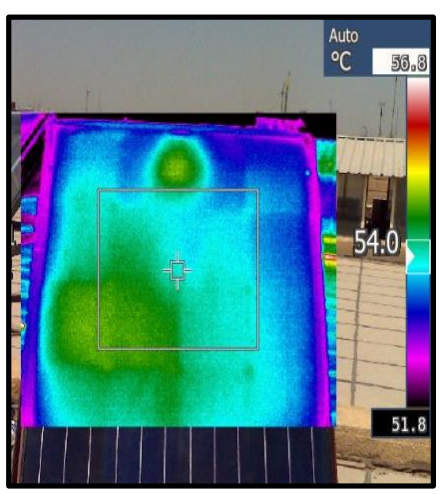

(a)

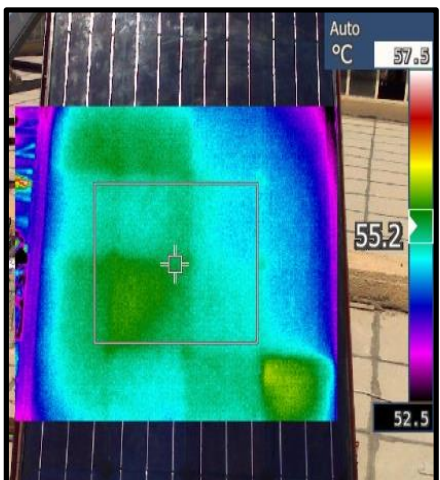

(b)

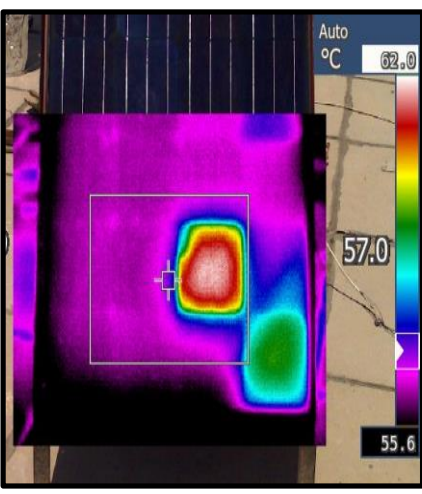

(c)

Figure 5: Shorted module after 2 houres of exposition to solar irradiance. (a): upper section, (b) medium section and (c) : lower section of PV module

\subsection{Increasing shading area on the hottest cell surface}

The experimental results obtained are reported in Table 2. However, the acquired I-V and P-V characteristics curve are depicted in Figures 6. Isc and consequently, Im values reduced clearly according to decreasing the illumination area of the solar cells. At no shading condition the Isc and Im values were 7.89A and 7.1A, while at $100 \%$ of the shaded area, they dropped to 6.88A and 5.88A for Isc and Im respectively. Moreover, the output power decreased as predicted, by taking from at normal operating from $107.92 \mathrm{~W}$ at no shading to $50.87 \mathrm{~W}$ at fully darken of the solar cell. Solar radiation difference between the second and third case lead to cause variance in recorded readings On the other side, the surface temperature explained briefly in thermal images in Figure 7. When the background temperature value is $44 \pm 1^{\circ} \mathrm{C}$ and solar radiation changed as explained in Table 2, the hottest cell temperature was $80.6,99.1,101.4$, and $62.4^{\circ} \mathrm{C}$ for $25,50,75$, and $100 \%$ of the shading area. Maximum temperature difference between the normal cell and the hottest cell was observed, it was 27.2, 48.6, 49.3, and 8.6 for at 25, 50, 75 and $100 \%$.the major temperature difference observed at $75 \%$ of the shading area.

Table 2: The results of the hottest cell under different shaded area

\begin{tabular}{ccccccc}
\hline $\begin{array}{c}\text { Shading Area } \\
(\mathbf{S A})\end{array}$ & $\mathbf{I}_{\mathbf{s c}}(\mathbf{A})$ & $\mathbf{I}_{\max }(\mathbf{A})$ & $\mathbf{V}_{\max }(\mathbf{V})$ & $\mathbf{P}_{\max }(\mathbf{W})$ & $\begin{array}{c}\mathbf{P}_{\text {losses }} \\
(\mathbf{\%})\end{array}$ & $\begin{array}{c}\mathbf{G} \\
\left(\mathbf{W} / \mathbf{m}^{\mathbf{2}}\right)\end{array}$ \\
\hline $0 \%$ & 7.89 & 7.1 & 15.2 & 107.92 & 0 & 912 \\
$25 \%$ & 5.97 & 4.72 & 14.36 & 67.78 & 37.17 & 908 \\
$50 \%$ & 4.76 & 3.6 & 15.3 & 55.11 & 50.05 & 880 \\
$75 \%$ & 7.12 & 5.9 & 9.4 & 55.46 & 48.61 & 967 \\
$100 \%$ & 6.88 & 5.88 & 8.64 & 50.87 & 52.86 & 932 \\
\hline
\end{tabular}




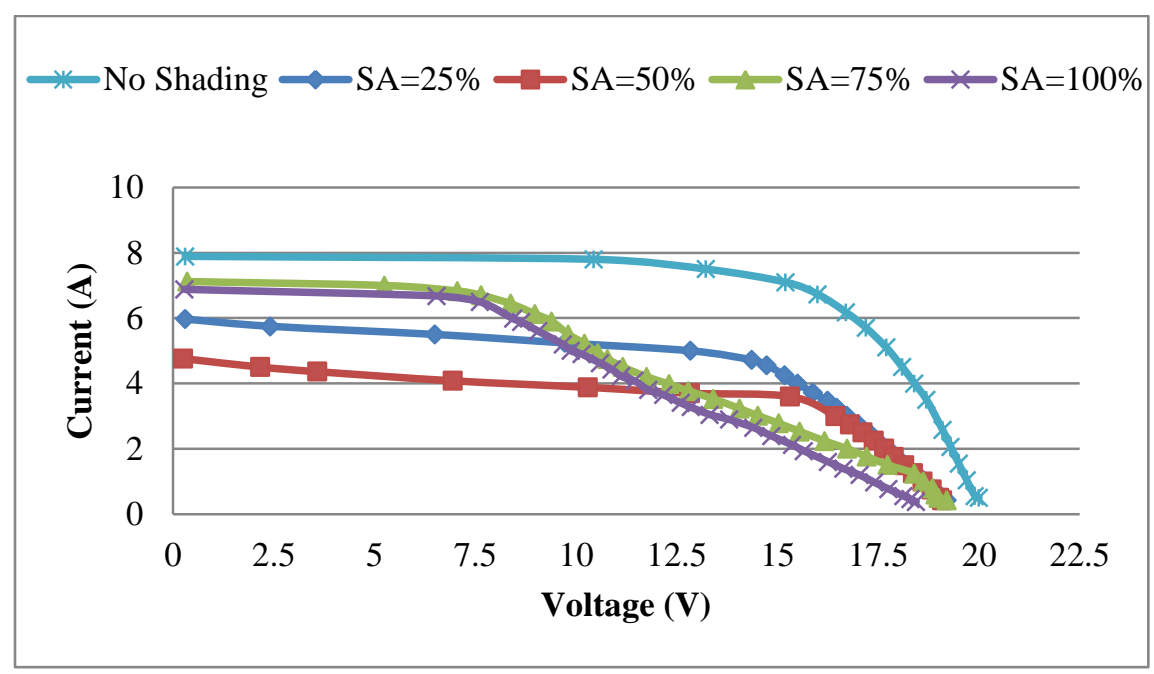

(a)

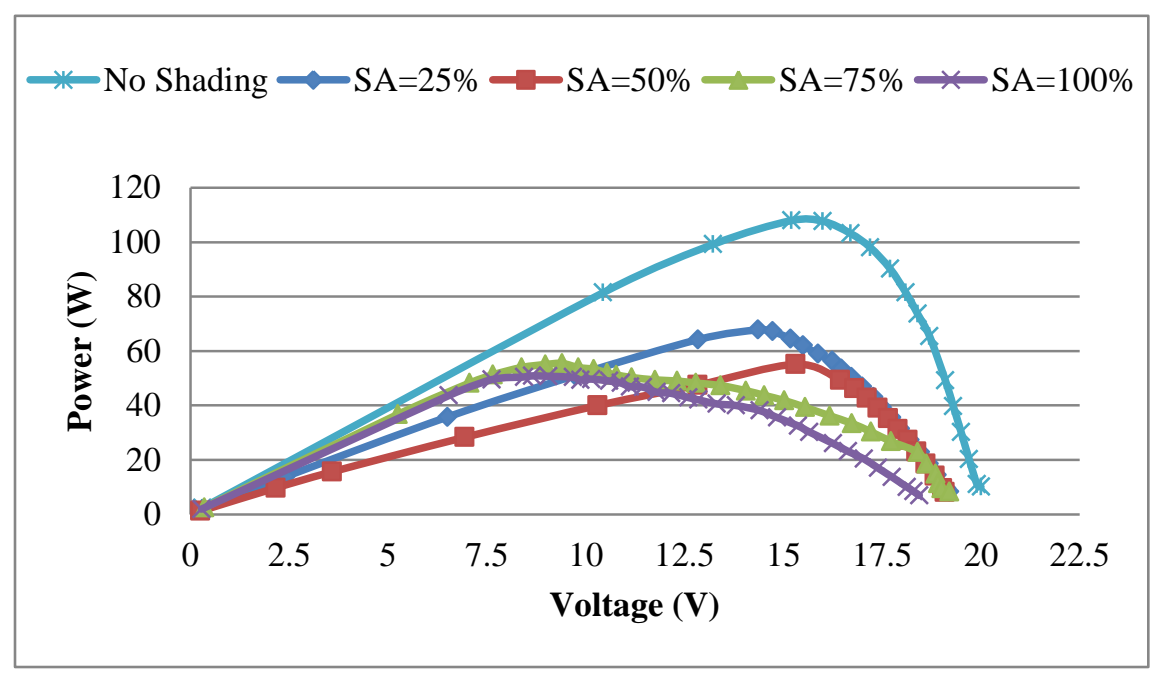

(b)

Figure 6: Recorded characteristics of PV panel under diagonally shading (a) I-V; (b) P-V

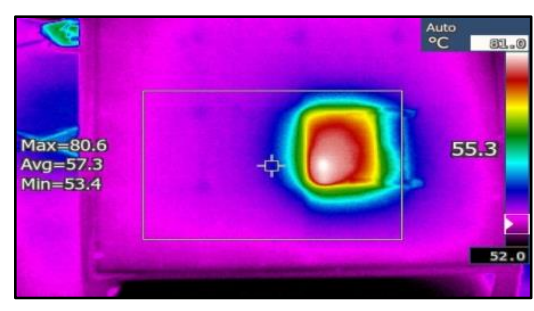

(a)

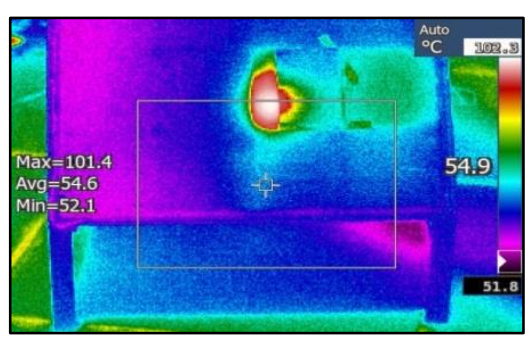

(c)

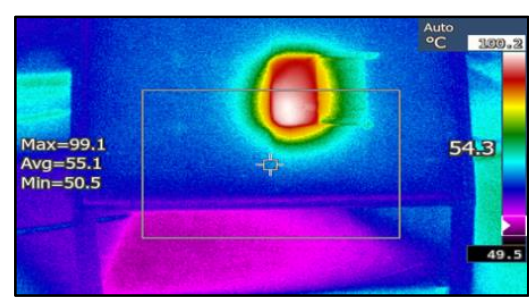

(b)

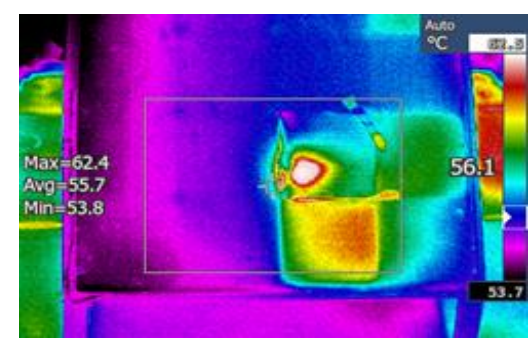

(d)

Figure 7: Hottest cell with different shaded area by cardboard (a) $25 \%$ of SA, (b) $50 \%$ of SA, (c) $75 \%$ of SA, and (d) $100 \%$ of SA 


\section{Conclusions}

The main findings can be drawn from the obtained results as

a) Hot spot power is the product of reverse bias voltage and current through the hot spot region and is predominantly dissipated as heat.

b) Isc and consequently, Im values reduced clearly according to decreasing the illumination area of the solar cells. At no shading condition the Isc and Im values were 7.89A and 7.1A, while at $100 \%$ of the shaded area, they dropped to 6.88A and 5.88A for Isc and Im respectively. Moreover, the output power decreased as predicted, by taking from at normal operating from $107.92 \mathrm{~W}$ at no shading to $50.87 \mathrm{~W}$ at fully darken of the solar cell.

c) At normal operating conditions $\left(\mathrm{G}=865 \mathrm{~W} / \mathrm{m} 2\right.$ and $\left.\mathrm{Ta}=39.7^{\circ} \mathrm{C}\right)$ the output power is $89.05 \mathrm{~W}$, the temperature difference between the hottest and cooled cell was about $6^{\circ} \mathrm{C}$.

d) Maximum temperature difference between the normal cell and the hottest cell was observed, it was 27.2, $48.6,49.3$, and 8.6 for at $25,50,75$ and $100 \%$.the major temperature difference observed at $75 \%$ of the shading area.

e) An infrared camera represents a key tool to quickly find hot spots.

\section{Author contribution}

All authors contributed equally to this work.

Funding

This research received no specific grant from any funding agency in the public, commercial, or not-for-profit sectors.

Data availability statement

The data that support the findings of this study are available on request from the corresponding author.

\section{Conflicts of interest}

The authors declare that there is no conflict of interest.

\section{References}

[1] M. Z. S. EL-Dein, M. Kazerani, and M. M. A. Salama, Optimal photovoltaic array reconfiguration to reduce partial shading losses, IEEE Trans. Sustain. Energy, 4 (2013) 145-153. https://doi.org/10.1109/TSTE.2012.2208128

[2] K. Sundareswaran, S. Peddapati and S. Palani, MPPT of PV systems under partial shaded conditions through a colony of flashing fireflies, IEEE Trans. on Energy Convers., 29 (2014) 463 - 472. https://doi.org/10.1109/TEC.2014.2298237

[3] M. Saadsaoud, H A. Abbasi, S.Kermiche and M.Ouada, Study of partial shading effects on photovoltaic arrays with comprehensive simulator for global MPPT control, Int. J. Renew. Energy Res., 6 (2016).

[4] S. Wendlandt, A. Drobisch, T. Buseth, S. Krauterand, P. Grunow, HOT spot risk analysis on silicon cell modules, 25th European Photovoltaic Solar Energy Conference and Exhibition /5th World Conference on Photovoltaic Energy Conversion, Valencia, Spain., (2010) 6-10. https://doi.org/10.4229/25thEUPVSEC2010-4AV.3.13

[5] R. Moretón , E. Lorenzo, L. Narvarte, Experimental observations on hot-spots and derived acceptance/rejection criteria, Sol. Energy., 118 (2015) 28-40. https://doi.org/10.1016/j.solener.2015.05.009

[6] S. Vishwakarma, Study of Partial shading effect on solar module using MATLAB, International Journal of Advanced Research in Electrical, electron. instrum. eng., 6 (2017) 5303-5308. https://doi.org/10.15662/IJAREEIE.2017.0607011

[7] W. He, F. Liu, J. Ji, S. Zhang, and H. chen, Safety Analysis of solar module under partial shading, Hindawi , Int. J. Photoenergy, 2015. https://doi.org/10.1155/2015/907282

[8] M. C. A. García, W. Herrmann, W. Bohmer, and B. Proisy, Thermal and electrical effects caused by outdoor hot-spot testing in associations of photovoltaic cells, Progr. Photovolt., Res. Appl., 11 (2003) $293-307$. https://doi.org/10.1002/pip.490

[9] J. W. Bishop, Computer simulation of the effects of electrical mismatches in photovoltaic cell interconnection circuits, Solar Cells, 25 (1988) 73-89. https://doi.org/10.1016/0379-6787(88)90059-2

[10] H. Yang, W. Hu, H. Wang, and M. Narayanan, Investigation of reverse current for crystalline silicon solar cells-New concept for a test standard about the reverse current, Proc. 35th IEEE Photovolt. Specialists Conf., (PVSC), USA, pp. 002806-002810, 2010. https://doi.org/10.1109/PVSC.2010.5616787 
[11] Cl. Buerhop , D. Schlegel , M. Niess , C.Vodermayer, R. Weißmann , C.J. Brabec , Reliability of IR-imaging of PVplants under operating conditions, Sol. Energy Mater Sol Cells., $107 \quad$ (2012) 154-164. https://doi.org/10.1016/j.solmat.2012.07.011

[12] A. M. Salazar, and E. Queen B. Macabebe, Hotspots detection in photovoltaic modules using infrared thermography, MATEC Web. Conf., 70 (2016). https://doi.org/10.1051/matecconf/20167010015.

[13] A. Dolara , G. C. Lazaroiu, E. Ogliari, Efficiency analysis of PV power plants shaded by MV overhead lines, J. Energy Environ. Eng., 7 (2016) 115-123. https://doi.org/10.1007/s40095-016-0208-2

[14] M. Dhimish, Fault detection and performance analysis of photovoltaic installations, PhD Thesis, University of Huddersfield, 2018. 